Pure Appl. Chem., Vol. 75, No. 5, pp. 589-599, 2003.

(C) 2003 IUPAC

\title{
Salt effects on the conformational behavior of 5-substituted 1,3-dioxanes*
}

\author{
Eusebio Juaristi ${ }^{\ddagger}$, Giselle A. Rosquete-Pina, \\ Maribel Vázquez-Hernández, and Antonio J. Mota \\ Departamento de Química, Centro de Investigación y de Estudios Avanzados del \\ Instituto Politécnico Nacional, Apartado Postal 14-740, 07000-México, D. F., México
}

Abstract: Since their introduction by E. L. Eliel nearly four decades ago, derivatives of 1,3-dioxane have proved useful in conformational analysis. Examples are discussed, where 5-polar substituents permit the evaluation of fundamental phenomena such as attractive and repulsive gauche effects, electrostatic interactions, and stereoelectronic effects. By the same token, 2-substituted 1,3-dioxanes, 1,3-dithianes, and 1,3-oxathianes are useful frameworks for the study of the anomeric effect and the associated structural and spectroscopic manifestations, such as the so-called Perlin effects. In view of the varied and essential involvement of metal ions and inorganic salts in biological processes, 5-substituted 1,3-dioxanes are presently being examined in the presence of $\mathrm{Li}^{+}, \mathrm{Na}^{+}, \mathrm{K}^{+}, \mathrm{Ag}^{+}, \mathrm{Mg}^{2+}, \mathrm{Ca}^{2+}, \mathrm{Ba}^{2+}$, and other cations, with the aim to increase the understanding of biomolecular properties in vivo.

\section{1,3-DIOXANES AS MODEL SYSTEMS IN CONFORMATIONAL ANALYSIS}

Interestingly, $\mathrm{H}$. Sachse's proposal of a strain-free, chair-shaped cyclohexane [1a] was published in 1890, the same year A. Baeyer advanced the idea that cyclohexane was planar (and thus strained) [1b]. Baeyer's model was favored during several decades, owing to the fact that rapid-ring inversion prevented isolation of the axial and equatorial isomers that should originate in monosubstituted cyclohexane derivatives (Scheme 1).

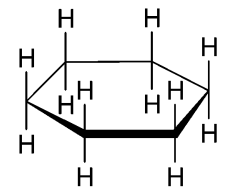

(a)

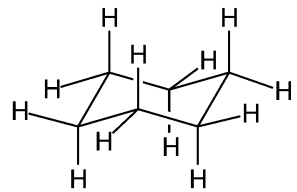

(b)

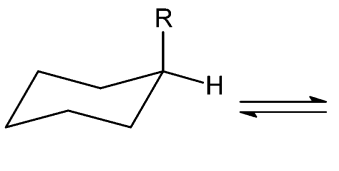

axial

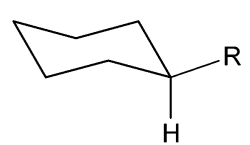

equatorial

(c)

Scheme 1 (a) Baeyer's planar cyclohexane. (b) Sachse's chair-shaped cyclohexane. (c) Interconversion of axial and equatorial isomers of monosubstituted cyclohexane derivatives via ring inversion.

In 1950, D. H. R. Barton demonstrated the fundamental importance of conformation (i.e., axial vs. equatorial orientation of the substituent) on chemical reactivity and molecular energy [2]. Indeed,

\footnotetext{
*Plenary lecture presented at the $16^{\text {th }}$ International Conference on Physical Organic Chemistry (ICPOC-16): Structure and Mechanism in Organic Chemistry, San Diego, California, USA, 4-9 August 2002. Other presentations are published in this issue, pp. 541-630.

¥Corresponding author: E-mail: juaristi@relaq.mx

Dedicated to Prof. Ernest L. Eliel on the occasion of his eightieth birthday.
} 
the conformational behavior of monosubstituted cyclohexanes effectively models larger and more complex molecules [3].

A quantitative procedure for the determination of the equilibrium constant ( $K=$ [equatorial]/ [axial]) in monosubstituted cyclohexanes was developed by Winstein and Holness [4a], and by Eliel's group [4b] in the mid-1950s. The central idea is that the behavior (reactivity, spectroscopic parameters) of a rapidly inverting compound is the weighted average of the behaviors of the individual axial and equatorial conformers. Because of the very large tendency of the tert-butyl to adopt the equatorial position, suitable 1,4-disubstituted cyclohexane derivatives serve as "anancomeric" (conformationally fixed) models for the pure axial and equatorial isomers (Scheme 2).

(a)

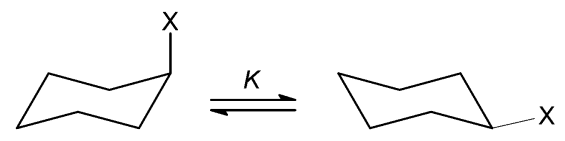

(b)

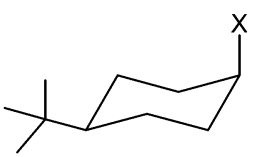

(c)

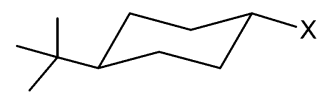

(d) $k=n_{\mathrm{eq}} k_{\mathrm{eq}}+\mathrm{n}_{\mathrm{ax}} k_{\mathrm{ax}}$

(e) $K=\left(\delta_{e q}-\delta_{o b s}\right) /\left(\delta_{o b s}-\delta_{a x}\right)$

(f) $\Delta G^{o}=-R T \ln K$

Scheme 2 (a) Mobile, rapidly inverting monosubstituted cyclohexane provides weighted average observables such as rate constants, $k_{\mathrm{obs}}$, and NMR chemical shifts, $\delta_{\mathrm{obs}}$. (b) Anancomeric model of the axial conformer. (c) Anancomeric model of the equatorial conformer. (d) Winstein's equation in terms of reaction rate constants. (e) Eliel's equation in terms of NMR chemical shifts. (f) Gibbs' equation.

The fact that many important natural products contain heteroatoms motivated the study of sixmembered rings incorporating oxygen, nitrogen, and sulfur atoms [5]. A particularly useful system for examination is that of 2,5-disubstituted 1,3-dioxanes, which are readily equilibrated with Lewis or Brønsted acids. Because of the short $\mathrm{C}-\mathrm{O}$ bonds in these molecules, groups smaller than tert-butyl can be employed as anchoring groups at $\mathrm{C}(2)$. Finally, the symmetry present in these dioxane derivatives facilitates the NMR analysis of equilibrating mixtures, in order to obtain the $K$ values of interest [5].

Table 1 presents selected data recorded by Eliel and coworkers [6], which provide evidence for the interplay of steric, electrostatic, and stereoelectronic interactions in these heterocycles (vide infra). Positive values for the observed conformational free-energy differences $\left(\Delta G^{\circ}\right)$ indicate a predominance of the cis (axial $\mathrm{X}$ ) diastereoisomer, whereas negative $\Delta G^{\circ}$ values correspond to exoergic processes where the trans (equatorial $\mathrm{X}$ ) diastereoisomer is more stable.

Salient results in Table 1 are: (1) The axial predominance of $\mathrm{F}$ (entry 1) and $\mathrm{CN}$ in $\mathrm{CH}_{3} \mathrm{CN}$ solvent (entry 5), in spite of the repulsive parallel alignment of the ring and $\mathrm{C}(5)-\mathrm{X}$ bond dipoles. For small and electronegative groups such as $\mathrm{F}$ and $\mathrm{CN}$, this behavior gives evidence of the so-called "attractive gauche effect" [7], which is usually explained in terms of a dominant nuclear-electron coulombic stabilization and/or stereoelectronic interactions. (2) In contrast with $\mathrm{F}$, halogens $\mathrm{Cl}$ and $\mathrm{Br}$ (entries 2 and 3 in Table 1) adopt preferentially the equatorial orientation, probably as a consequence of repulsive orbital overlap between the lone pairs at the endocyclic oxygens and $\mathrm{Cl}$ or $\mathrm{Br}$; i.e., the larger van der Waals radius of $\mathrm{Cl}$ and $\mathrm{Br}$ relative to $\mathrm{F}$ plays a determining part in their different behavior. (3) Polar solvents reduce dipole-dipole repulsion, favoring the conformation that has the higher dipole moment. Compare entries 4 and 5, where the trans (less polar) isomer is favored in $\mathrm{Et}_{2} \mathrm{O}$ but where the cis (more polar) isomer is predominant in $\mathrm{CH}_{3} \mathrm{CN}$.

Eliel et al. [6] discovered also that the $\mathrm{CH}_{3} \mathrm{~S}$ group (entry 6 in Table 1) has a stronger preference for the equatorial conformation $\left(\Delta G^{\circ}=-1.82 \mathrm{kcal} / \mathrm{mol}\right.$ ) than that measured for (methylthio)cyclohexane $\left(\Delta G^{\circ}=-1.0 \mathrm{kcal} / \mathrm{mol}\right)$, presumably as a result of a repulsive interaction of the unshared electrons of sulfur with the unshared electrons of the ring oxygens. In strong contrast, $\mathrm{CH}_{3} \mathrm{~S}(\mathrm{O})$ and 
Table 1 Conformational equilibria in 2,5-disubstituted 1,3-dioxanes [6].

\begin{tabular}{llll} 
Entry & Substituent $\mathrm{X}$ & Solvent & $\Delta G_{25{ }^{\circ} \mathrm{C}}(\mathrm{kcal} / \mathrm{mol})$ \\
\hline 1 & $\mathrm{~F}$ & $\mathrm{C}_{6} \mathrm{H}_{6}$ & $+0.83 \pm 0.04$ \\
2 & $\mathrm{Cl}$ & $\mathrm{C}_{6} \mathrm{H}_{6}$ & $-0.89 \pm 0.05$ \\
3 & $\mathrm{Br}$ & $\mathrm{C}_{6} \mathrm{H}_{6}$ & $-1.17 \pm 0.05$ \\
4 & $\mathrm{CN}$ & $\mathrm{Et}_{2} \mathrm{O}_{\text {trans }}$ & $-0.21 \pm 0.04$ \\
5 & $\mathrm{CN}$ & $\mathrm{CH}_{3} \mathrm{CN}$ & $+0.55 \pm 0.03$ \\
6 & $\mathrm{SCH}$ & $\mathrm{C}_{6} \mathrm{H}_{12}$ & $-1.82 \pm 0.01$ \\
7 & $\mathrm{~S}_{3}(\mathrm{O}) \mathrm{CH}_{3}$ & $\mathrm{CHCl}_{3}$ & $+0.82 \pm 0.11$ \\
8 & $\mathrm{SO}_{2} \mathrm{CH}_{3}$ & $\mathrm{CHCl}_{3}$ & $+1.19 \pm 0.10$ \\
\hline
\end{tabular}

$\mathrm{CH}_{3} \mathrm{SO}_{2}$ (entries 7 and 8) prefer the axial conformation. This unusual behavior was rationalized in terms of an attractive electrostatic interaction between the negative endocyclic oxygens and the positive sulfinyl or sulfonyl group (Scheme 3a).

(a)

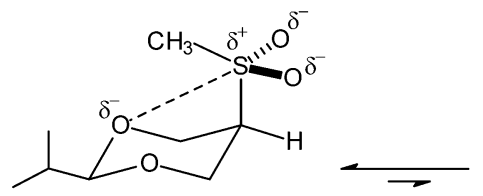

$\Delta G^{\circ}(\mathrm{kcal} / \mathrm{mol})$<smiles>CC(C)C1OCC(S(=O)(=O)O)CO1</smiles>

$+1.19$

(b)
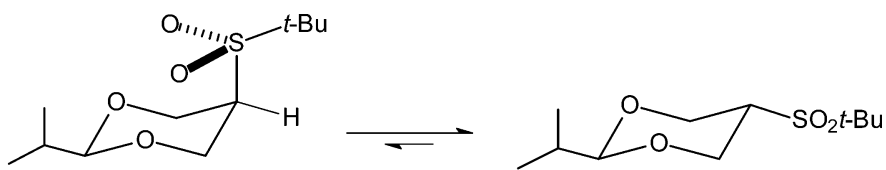

(eclipsed!)<smiles>C=CCC(C)C(=O)OCC(C)(C)C</smiles><smiles>C=CCOC(=O)C1CC2(C1)SC(C(C)(C)C)S2</smiles><smiles>CC(C)(C)C1SCC(O[S+](C)(=O)=O)CS1</smiles>

$-1.50$

Scheme 3 Contrasting conformational behavior in (a) cis- and trans-2-isopropyl-5-methylsulfonyl-1,3-dioxane [6], (b) cis- and trans-2-isopropyl-5-tert-butylsulfonyl-1,3-dioxane [8], and (c) cis- and trans-2-tert-butyl-5-methylsulfonyl-1,3-dithiane [9].

In this context, the positions of equilibrium between diastereomeric tert-butyl analogs were studied by Juaristi et al. [8]. Although $\Delta G^{\circ}$ values for sulfides are very similar, the difference in conformational behavior for the sulfoxides is significant, and the effect of changing from methyl to tert-butyl in the sulfones is quite dramatic: the large preference of the methyl analog for the axial position $(+1.19$ $\mathrm{kcal} / \mathrm{mol}$, entry 7 in Table 1) is reversed in the tert-butyl derivative, where the equatorial isomer is more stable by $1.14 \mathrm{kcal} / \mathrm{mol}$. A crystallographic X-ray diffraction study revealed a conformation with eclipsed $\mathrm{S}-\mathrm{O} / \mathrm{C}-\mathrm{C}$ and $\mathrm{S}-\mathrm{C} / \mathrm{C}-\mathrm{H}$ bonds (Scheme $3 \mathrm{~b}$ ) [8]. 
Table 2 Conformational equilibria ( $\mathrm{kcal} / \mathrm{mol})$, and magnitude of the attractive gauche effect, in 5-substituted 1,3-dioxanes [10].

\begin{tabular}{lcccc} 
& $\Delta G_{\text {cyclohexane }}^{\circ}$ & $\Delta G^{\circ}$ steric & $\begin{array}{c}\Delta \Delta G^{\circ} \\
\text { (gauche effect) }\end{array}$ \\
\hline $\mathrm{R}$ & $\Delta G_{\text {exptl }}^{\circ}$ & -0.55 & -0.29 & $\mathbf{0 . 0 5}$ \\
$\mathrm{CH}_{3}$ & -0.24 & -0.52 & -0.26 & $\mathbf{0 . 2 5}$ \\
$\mathrm{SO}_{2} \mathrm{C}_{6} \mathrm{H}_{4}-p-\mathrm{CH}_{3}$ & -0.01 & $(-0.52)$ & -0.26 & $\mathbf{0 . 6 0}$ \\
$\mathrm{SO}_{2} \mathrm{CH}_{3}$ & +0.34 & -0.56 & -0.26 & $\mathbf{0 . 7 4}$ \\
$\mathrm{SO}_{2} \mathrm{C}_{6} \mathrm{H}_{4}-p-\mathrm{NO}_{2}$ & +0.48 & & &
\end{tabular}

More recently, the conformational analysis of cis- and trans-2-tert-butyl-5-methylsulfonyl-1,3-dithiane was carried out (Scheme 3c)[9]. It is observed that the trans diastereomer is more stable than the cis isomer by $1.50 \mathrm{kcal} / \mathrm{mol}$. Furthermore, steric and electrostatic repulsion in the axial methylsulfonyl group leads to the cis sulfone adopting a twist-boat, rather than a chair conformation (Scheme 3c).

Quantitation of the $\mathrm{O}-\mathrm{C}-\mathrm{C}-\mathrm{O}$ attractive gauche effect [7] in $O$-5-substituted 1,3-dioxanes (Table 2) revealed substantial differences, depending on whether the substituent is tosylate, nosylate, and mesylate. No significant attractive gauche effect was observed for the 5-methoxy derivative (entry 1 in Table 2). Good correlations between the magnitude of the attractive gauche effect and the positive character of the antiperiplanar hydrogens $\left(\mathrm{H}-4,6_{\mathrm{ax}}\right)$ in the cis diastereomers, as well as the nucleofugicity of the 5-substituents, support a hyperconjugative $\sigma_{\mathrm{C}-\mathrm{H}} \rightarrow \sigma^{*}{ }_{\mathrm{C}-\mathrm{OR}}$ interpretation of the attractive gauche effect [10] (eq. 1).

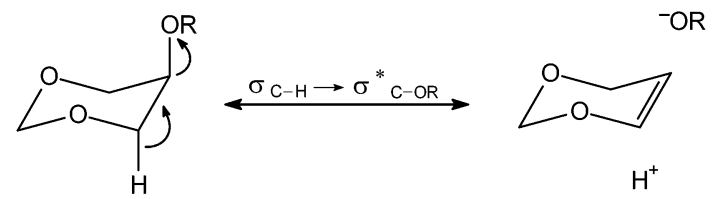

It was mentioned above that substituents in cyclohexane prefer the equatorial over the axial position. Nevertheless, it was discovered that electronegative substituents at the anomeric carbon in pyranose derivatives present a tendency to adopt the axial orientation. This is the "anomeric effect", that as suggested by Eliel [11], is probably the most studied topic in physical organic chemistry since carbocations! The extraordinary interest attracted by the study of the anomeric effect is due to the fact that the fundamental interactions responsible for the unusual conformational behavior seem to be also responsible for the reactivity patterns and stereochemical outcome of many chemical and biochemical reactions [12].

Scheme 4 presents two applications of 2-substituted 1,3-dioxane and 1,3-dithiane derivatives to the evaluation of anomeric effects [13]. As sketched in Scheme 4, both electrostatic dipole-dipole and stereoelectronic $n_{X} \rightarrow \sigma_{C-Y}^{*}$ interactions are involved in the stabilization of the axial conformers. 
(a)

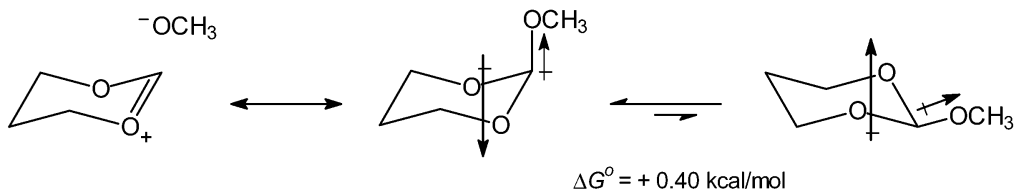

(b)

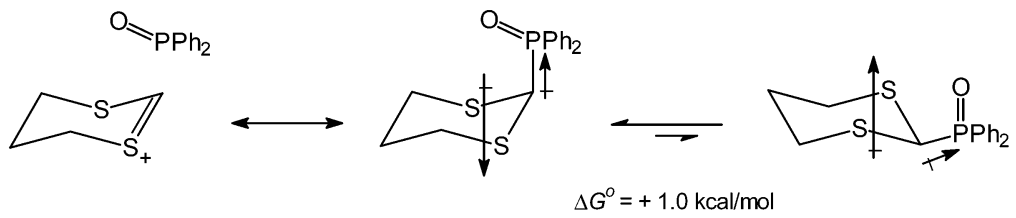

Scheme 4 (a) Anomeric effect in 2-methoxy-1,3-dioxane [13a]. (b) Anomeric effect in 2-diphenylphosphinoyl-1,3dithiane [13b].

Particularly useful in this area of study are spectroscopic manifestations of stereoelectronic interactions. In an insightful observation, Perlin and Casu [14] reported that the magnitude of the one-bond ${ }^{13} \mathrm{C}-{ }^{1} \mathrm{H}$ coupling constant for an axial $\mathrm{C}-\mathrm{H}$ bond adjacent to oxygen or nitrogen in a six-membered ring is substantially smaller (by $8-10 \mathrm{~Hz}$ ) than ${ }^{1} J_{\mathrm{C}-\mathrm{H}}$ for an equatorial C-H bond; that is, ${ }^{1} J_{\mathrm{C}-\mathrm{Hax}}<{ }^{1} J_{\mathrm{C}-\mathrm{Heq}}$. This finding has been explained in terms of an $n_{X} \rightarrow \sigma^{*}{ }_{C-H a x}(X=O, N)$ interaction between a pair of nonbonded electrons on oxygen or nitrogen and the axial (antiperiplanar) adjacent $\mathrm{C}-\mathrm{H}$ bond, which weakens such $\mathrm{C}-\mathrm{H}_{\mathrm{ax}}$ bond and attenuates the Fermi contribution to the one-bond ${ }^{13} \mathrm{C}-{ }^{1} \mathrm{H}$ coupling constant (eq. 2).

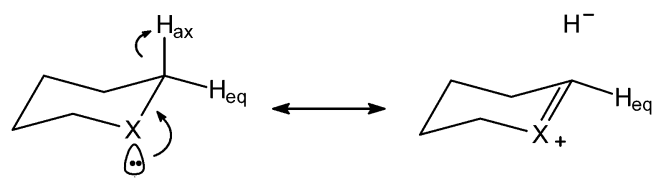

Nevertheless, Bailey et al. [15] discovered in 1988 that, in contrast with the situation in cis-4,6-dimethyl-1,3-dioxane (A, Scheme 5) where ${ }^{1} J_{\mathrm{C}(2)-\mathrm{Hax}}=157.4 \mathrm{~Hz}<{ }^{1} J_{\mathrm{C}(2)-\mathrm{Heq}}=167.5 \mathrm{~Hz}$, the 1,3-dithiane analog $\mathbf{B}$ (Scheme 5) exhibits an opposite behavior: ${ }^{1} J_{\mathrm{C}(2)-\mathrm{Hax}}=154.1 \mathrm{~Hz}>{ }^{1} J_{\mathrm{C}(2)-\mathrm{Heq}}=144.9 \mathrm{~Hz}$.

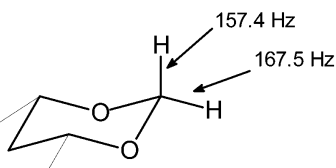

A

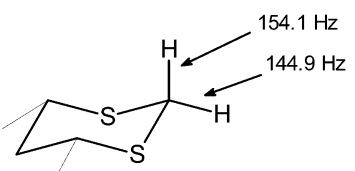

B

Scheme 5 Contrasting Perlin effects in 1,3-dioxane and 1,3-dithiane heterocycles [15].

This reversal of the relative magnitudes of the coupling constants was explained by Wolfe et al. [16], in terms of a dominant $\sigma_{\mathrm{C}-\mathrm{S}} \rightarrow \sigma^{*}{ }_{\mathrm{C}-\mathrm{Heq}}$, rather than $\mathrm{n}_{\mathrm{S}} \rightarrow \sigma_{\mathrm{C}-\mathrm{Hax}}{ }$, interaction in B. Juaristi and coworkers [17] provided experimental and theoretical support for such interpretation (Scheme 6).

A different form of hyperconjugation has been documented for substituted $\pi$-systems. In particular, sigma $\mathrm{C}-\mathrm{H}$ bonds can in principle act as electron donors to adjacent $\pi$ double bonds or carbonyl groups as depicted in eq. 3 [19].

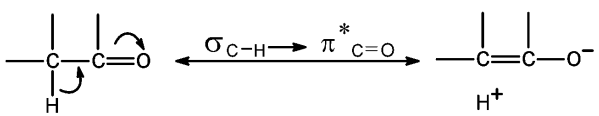


(a)

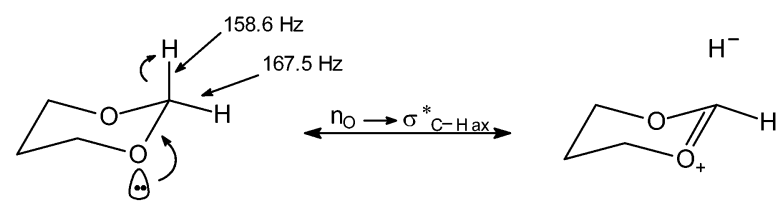

(b)

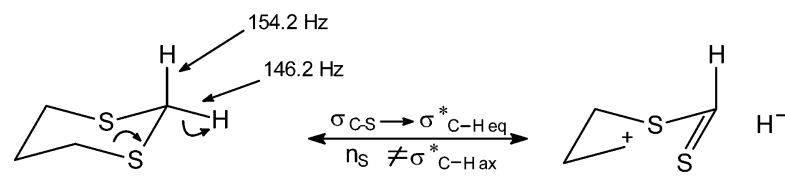

$\mathrm{H}^{-}$

(c)

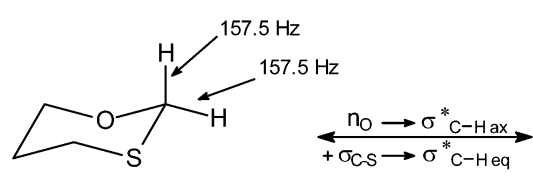<smiles>SCC1=[O+]CCCS1</smiles><smiles>[BH3-]C1OCC[C@H]1S</smiles>

Scheme 6 Perlin effects in (a) 1,3-dioxane, (b) 1,3-dithiane, and (c) 1,3-oxathiane [17,18].

Theoretical determination [B3LYP/6-31G $(d, p)$ and PP/IGLO//B3LYP/6-31G $(d, p)$ methods] of the structural (in particular, $\mathrm{C}-\mathrm{H}$ bond distances) and spectroscopic (specifically, one-bond ${ }^{1} J_{\mathrm{C}-\mathrm{H}}$ NMR-coupling constants) consequences of stereoelectronic hyperconjugative effects in several heteroatom-containing cyclohexanone derivatives (Scheme 7) confirm the importance of $\mathrm{n}_{\mathrm{O}} \rightarrow \sigma_{\mathrm{C}-\mathrm{Hax}}^{*}$, $\sigma_{\mathrm{C}-\mathrm{Hax}} \rightarrow \pi_{\mathrm{C}=\mathrm{O}}^{*}, \sigma_{\mathrm{C}-\mathrm{S}} \rightarrow \sigma_{\mathrm{C}-\mathrm{H}}^{*}$, and $\sigma_{\mathrm{C}-\mathrm{Hax}} \rightarrow \sigma^{*}{ }_{\mathrm{C}-\mathrm{Hax}}$ hyperconjugation. Furthermore, calculated $\mathrm{C}-\mathrm{H}$ bond lengths and ${ }^{1} J_{\mathrm{C}-\mathrm{H}}$ coupling constants for $\mathrm{C}-\mathrm{H}$ bonds participating in more than one hyperconjugative interaction show additivity of the effects (Scheme 7) [20].
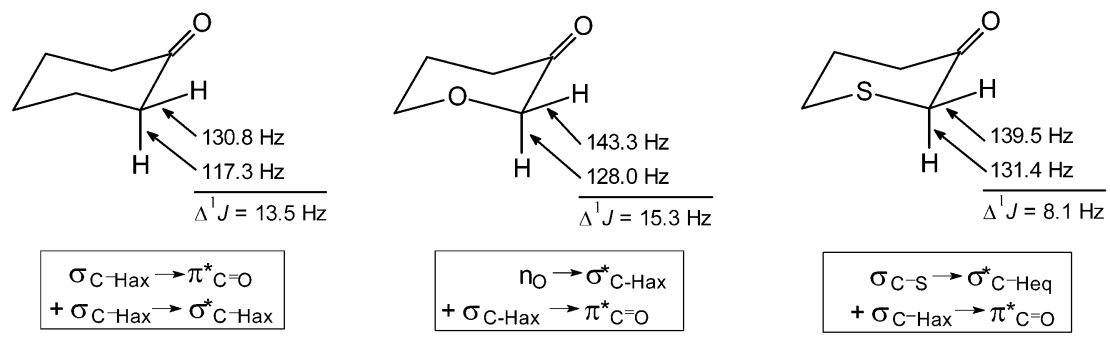

Scheme 7 Additivity of stereoelectronic interactions on C-H one-bond coupling constants [20].

\section{METAL ION AND SALT EFFECTS IN CHEMISTRY AND BIOCHEMISTRY}

The importance of reaction media is enormous and well appreciated. Most organic reactions are carried out in solution, and in this regard, solvents are frequently modified by additives such as cosolvents, complexing agents, and "inert" salts [21,22]. Scheme 8 shows two examples of salt effects on the course of such reactions.

Many biological processes such as enzymatic activity, molecular recognition, and signal transduction depend on the presence and interaction of free metal ions and inorganic salts [24a]. A dramatic example is the sequence of events that is triggered by $\mathrm{Ca}^{2+}$ coordination to calmoludin, a protein that then undergoes substantial structural changes, becomes activated, and in turn activates other enzymes involved in muscle contraction [24b]. Furthermore, metal ion complexation may lead to conformational changes that alter the biological activity of natural and synthetic substances. For example, a recent study 
(a)

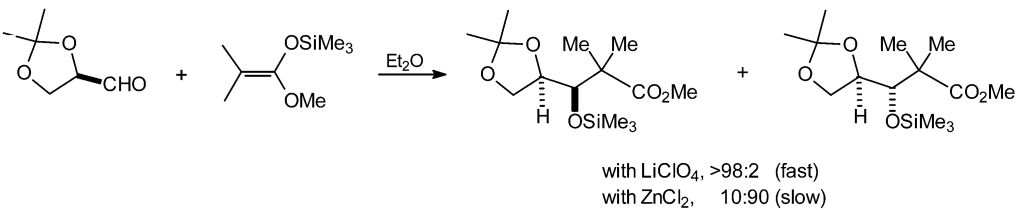

(b)
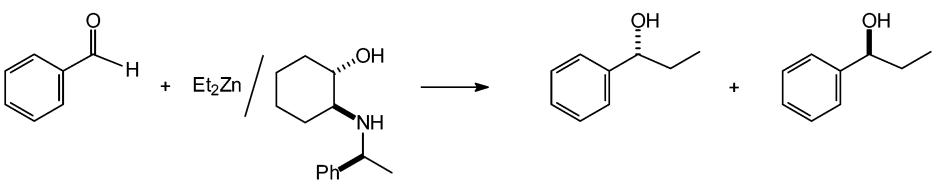

$\begin{array}{ll}\text { without salt, } & 74: 26 \\ \text { with } \mathrm{LiCl}, & 32: 68\end{array}$

Scheme 8 (a) Salt effects in Mukaiyama's aldol addition [23a]. (b) $\mathrm{Et}_{2} \mathrm{Zn}$ addition to benzaldehyde [23b].

provides evidence for the $\mathrm{Fe}^{3+}$ effect that reduces the toxicity of gossipol [24c]. Interestingly, the activity of antitumor antibiotic (+)-duocarmycin SA correlates with the relative stability of its metal complexes $\left(\mathrm{Cu}^{2+}>\mathrm{Ni}^{2+}>\mathrm{Zn}^{2+}>\mathrm{Mn}^{2+}>\mathrm{Mg}^{2+}\right)$, providing the opportunity to "tune" the drug activity profile $[24 \mathrm{~d}]$.

Other pertinent references relate to transport of $\mathrm{K}^{+}$ions through protein channels, which is fundamental to electrical signal in biological systems. Monensin is a ionophoric antibiotic that is known to complex alkali metal ions in order to transport them across biological membranes. Recent NMR experiments by Riddell [25] provide considerable insight into the mechanisms of transport.

Increased knowledge of the interaction of free metal ions and inorganic salts is vital to the understanding of biomolecular properties in vivo, and there is also intense interest in the design and synthesis of molecules that could mimic biological ion carriers or receptors [26].

\section{SALT EFFECTS ON THE CONFORMATIONAL BEHAVIOR OF 1,3-DIOXANES}

In view of the advantages offered by 1,3-dioxane derivatives for the evaluation of conformational effects (vide supra), a few years ago we carried out the preparation and chemical equilibration of a series of 5-substituted 1,3-dioxanes 1-8, both in the presence and absence of lithium bromide [27]. Equilibration of diastereomeric 1,3-dioxanes (cis- and trans-1-8) afforded the corresponding free-energy differences, that are summarized in Table 3.

The salt effects measured in this work [27] revealed three tendencies upon salt addition: (1) increased axial preference in the equilibria of dioxanes $\mathbf{1}\left(\mathrm{X}=\mathrm{CO}_{2} \mathrm{H}\right)$ and $\mathbf{4}\left(\mathrm{X}=\mathrm{CH}_{2} \mathrm{OH}\right)$, increased equatorial preference for $\mathbf{8}\left(\mathrm{X}=\mathrm{NHCOCH}_{3}\right)$, and (3) no significant salt effect for the conformational equilibria of 2, 3, and 5-7. Interpretation of these results was aided by spectroscopic (IR, NMR) analysis, as well as molecular modeling (AM1) studies, and led to the proposal of species $\mathbf{C}$ and $\mathbf{D}$ (Scheme 9) as responsible for the stabilization of cis (axial) 1 and 4 [28].

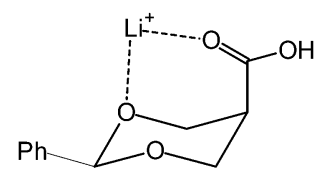

C

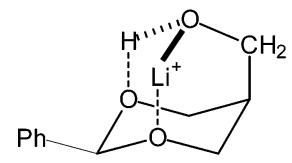

Scheme 9 Proposed coordination of $\mathrm{Li}^{+}$to cis-1 (C) and cis-4 (D). 
Table 3. Conformational equilibria in 5-substituted-2-phenyl1,3-dioxanes 1-8, in the absence or presence of $\mathrm{LiBr}$, at $25^{\circ} \mathrm{C}$ in THF [27].

\begin{tabular}{|c|c|c|c|c|}
\hline \multirow[t]{2}{*}{ compd } & \multirow[t]{2}{*}{$\mathrm{X}$} & \multicolumn{3}{|c|}{$\Delta G^{\circ}(\mathrm{kcal} / \mathrm{mol})$} \\
\hline & & 0.0 equiv & 1.0 equiv & 10 equiv \\
\hline 1 & $\mathrm{CO}_{2} \mathrm{H}$ & -0.77 & -0.41 & -0.17 \\
\hline 2 & $\mathrm{CO}_{2} \mathrm{Me}$ & -0.50 & -0.15 & -0.43 \\
\hline 3 & CONHMe & -0.76 & -0.67 & -0.60 \\
\hline 4 & $\mathrm{CH}_{2} \mathrm{OH}$ & -0.20 & -0.04 & +0.22 \\
\hline 5 & $\mathrm{OH}$ & -0.38 & -0.35 & -0.43 \\
\hline 6 & OCOMe & +0.47 & +0.45 & +0.43 \\
\hline 7 & $\mathrm{NO}_{2}$ & +0.73 & +0.52 & +0.57 \\
\hline 8 & NHCOMe & +0.94 & +0.44 & -0.13 \\
\hline
\end{tabular}

On the other hand, the dramatic reversal of conformational preference in dioxane $\mathbf{8}$, from a robust axial predominance in the absence of salt $\left(\Delta G^{\circ}=+0.94 \mathrm{kcal} / \mathrm{mol}\right)$ to a clear preference for the equatorial orientation in the presence of 10 equiv of $\operatorname{LiBr}\left(\Delta G^{\circ}=-0.13 \mathrm{kcal} / \mathrm{mol}\right)$ was explained in terms of a disruption of an intramolecular hydrogen bond (eqs. 4 and 5) [27].<smiles>CC(=O)N1[C@H]2COC(c3ccccc3)(O2)[C@H]1[O+]</smiles><smiles></smiles>

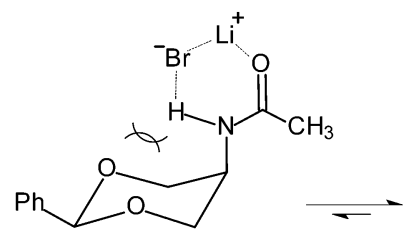<smiles></smiles>

We now have extended the conformational study of 5-carboxy dioxane (cis-1 $\rightleftharpoons$ trans-1) to include $\mathrm{Na}^{+}, \mathrm{K}^{+}, \mathrm{Ag}^{+}, \mathrm{Mg}^{2+}, \mathrm{Ca}^{2+}$, and $\mathrm{Ba}^{2+}$. The results are collected in Table 4 and provide evidence for stabilization of the axial isomer in the presence of most cations, except $\mathrm{Ca}^{2+}$ and $\mathrm{Ba}^{2+}$. The relative magnitude of the effects is $\mathrm{Ag}^{+}>>\mathrm{Li}^{+}>\mathrm{Mg}^{2+}, \mathrm{Na}^{+}>\mathrm{K}^{+}$.

Calculated metal ion effects on the conformational equilibrium of 5-carboxy-1,3-dioxane, at the Becke3LYP/6-31+G $(d, p)$ level of theory, generally reproduced the experimental results (Table 5). Of course, the gas-phase calculations give $\Delta E$ values that are rather large for equilibria involving ionic species. Nevertheless, the relative magnitude of the metal ion effects is $\mathrm{Mg}^{2+}>\mathrm{Li}^{+}, \mathrm{Ca}^{2+}>\mathrm{Na}^{+}>\mathrm{K}^{+}$, to be compared with the experimentally determined data: $\mathrm{Li}^{+}>\mathrm{Mg}^{2+}, \mathrm{Na}^{+}>\mathrm{K}^{+}$. The experimental observation that $\mathrm{Ca}^{2+}$ stabilizes trans-1 is surprising, and is presently being corroborated. 
Table 4 Chemical equilibration of 5-carboxy-2-phenyl-1,3dioxanes (cis- and trans-1) in the absence or presence of salt, at $25{ }^{\circ} \mathrm{C}$.

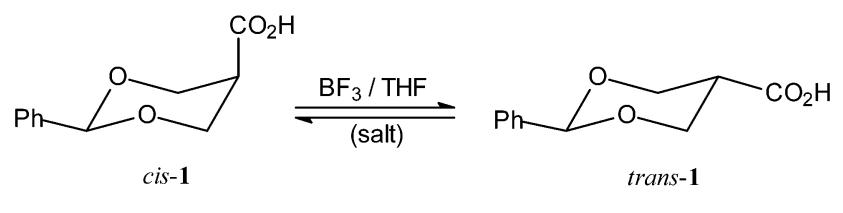

\begin{tabular}{|c|c|c|}
\hline & \multicolumn{2}{|c|}{$\Delta G^{\circ}(\mathrm{kcal} / \mathrm{mol})$} \\
\hline & 1.0 equiv & 5.0 equiv \\
\hline - & \multicolumn{2}{|c|}{-0.80} \\
\hline $\mathrm{LiBr}$ & -0.41 & -0.17 \\
\hline $\mathrm{Na}$ (OTf) & -0.34 & -0.28 \\
\hline K (OTf) & -0.76 & -0.54 \\
\hline $\mathrm{Ag}$ (OTf) & -0.43 & +0.80 \\
\hline $\mathrm{Mg}(\mathrm{OTf})_{2}$ & -0.91 & -0.26 \\
\hline $\mathrm{Ca}(\mathrm{OTf})_{2}$ & -0.92 & -1.59 \\
\hline $\mathrm{Ba}(\mathrm{OTf})_{2}$ & -0.63 & -0.64 \\
\hline
\end{tabular}

Table 5 Calculated [Becke3LYP/6-31G $(d)$ ] metal ion effects on the conformational equilibrium of 5-carboxy-1,3-dioxane.

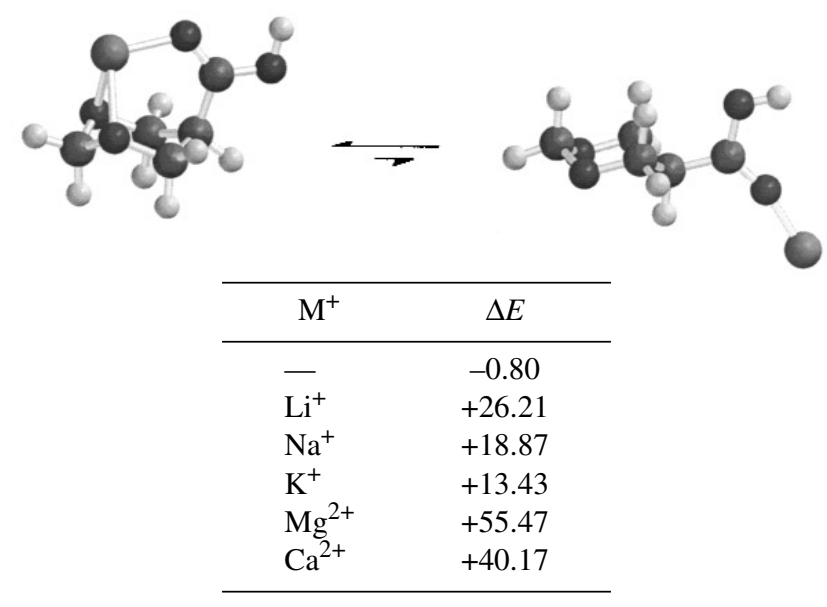




\section{REFERENCES}

1. (a) H. Sachse. Ber. Dtsch. Chem. Ges. 23, 1363 (1890); (b) A. Baeyer. Justus Liebigs Ann. Chem. 258, 145 (1890).

2. D. H. R. Barton. Experientia 6, 316 (1950).

3. (a) E. L. Eliel, N. L. Allinger, S. J. Angyal, G. A. Morrison. Conformational Analysis, Interscience, New York (1965); (b) E. Juaristi. Introduction to Stereochemistry and Conformational Analysis, Wiley, New York (1991); (c) E. L. Eliel, S. H. Wilen, L. N. Mander. Stereochemistry of Organic Compounds, Wiley, New York (1994); (d) E. Juaristi (Ed.). Conformational Behavior of Six Membered Rings: Analysis, Dynamics, and Stereoelectronic Effects, VCH, New York (1995).

4. (a) S. Winstein and N. J. Holness. J. Am. Chem. Soc. 77, 5562 (1955); (b) E. L. Eliel and R. S. Ro. Chem. Ind. (London) 251 (1956).

5. E. L. Eliel. Acc. Chem. Res. 3, 1 (1970).

6. M. K. Kaloustian, N. Dennis, S. Mager, S. A. Evans, F. Alcudia, E. L. Eliel. J. Am. Chem. Soc. 98, 956 (1976).

7. (a) S. Wolfe. Acc. Chem. Res. 5, 102 (1972); (b) E. Juaristi. J. Chem. Educ. 56, 438 (1979).

8. E. Juaristi, R. Martínez, R. Méndez, R. A. Toscano, M. Soriano-García, E. L. Eliel, A. Petsom, R. S. Glass. J. Org. Chem. 52, 3806 (1987).

9. E. Juaristi and J. S. Cruz-Sánchez. Tetrahedron Lett. 43, 9369 (2002).

10. E. Juaristi and S. Antúnez. Tetrahedron 48, 5941 (1992).

11. E. L. Eliel. "100+ Years of Conformational Analysis", E. Juaristi (Ed.), Conformational Behavior of Six Membered Rings: Analysis, Dynamics, and Stereoelectronic Effects, VCH, New York (1995).

12. For reviews on the anomeric effect, see: (a) W. A. Szarek and D. Horton (Eds.). Anomeric Effect. Origin and Consequences, ACS Symposium Series 87, American Chemical Society, Washington, DC (1979); (b) A. J. Kirby. The Anomeric Effect and Related Stereoelectronic Effects at Oxygen, Springer, New York (1983); (c) E. Juaristi and G. Cuevas. Tetrahedron 48, 5019 (1992); (d) G. R. J. Thatcher, (Ed.). The Anomeric Effect and Associated Stereoelectronic Effects, American Chemical Society, Washington, DC (1993); (e) P. P. Graczyk and M. Mikolajczyk. Top. Stereochem. 21, 159 (1994); (f) E. Juaristi and G. Cuevas. The Anomeric Effect, CRC Press, Boca Raton, FL (1995); (g) C. L. Perrin. Acc. Chem. Res. 35, 28 (2002).

13. (a) E. L. Eliel and C. A. Giza. J. Am. Chem. Soc. 33, 3754 (1968). See, also: C. Romers, C. Altona, H. R. Buys, E. Havinga. Top. Stereochem. 4, 39 (1969); (b) E. Juaristi, L. Valle, B. A. Valenzuela, M. A. Aguilar. J. Am. Chem. Soc. 108, 2000 (1986). See, also: K. Arai, H. Iwamura, M. Oki. Bull. Chem. Soc. Jpn. 48, 3319 (1975).

14. A. S. Perlin and B. Casu. Tetrahedron Lett. 2921 (1969).

15. W. F. Bailey, A. D. Rivera, K. Rossi. Tetrahedron Lett. 29, 5621 (1988).

16. S. Wolfe, B. M. Pinto, V. Varma, R. Y. N. Yeung. Can. J. Chem. 68, 1051 (1990).

17. (a) E. Juaristi, G. Cuevas, A. Vela. J. Am. Chem. Soc. 116, 5796 (1994); (b) G. Cuevas, E. Juaristi, A. Vela. J. Phys. Chem. A 103, 932 (1999).

18. For a recent theoretical study, see: I. V. Alabugin. J. Org. Chem. 65, 3910 (2000).

19. See, for example: A. J. Kirby. Stereoelectronic Effects, pp. 25-26 Oxford Science Publications, Oxford (1996).

20. G. Cuevas and E. Juaristi. J. Am. Chem. Soc. 124, 13088 (2002).

21. (a) C. Reichardt. Solvents and Solvent Effects in Organic Chemistry, $2^{\text {nd }}$ ed., VCH, Weinheim (1988); (b) A. Loupy, B. Tchoubar, D. Astruc. Chem. Rev. 92, 1141 (1992).

22. (a) D. Seebach, A. K. Beck, A. Studer. Modern Synthetic Methods 1995, pp. 1-178, VCH, Weinheim (1995); (b) See, also: E. Juaristi, A. K. Beck, J. Hansen, T. Matt, T. Mukhopadhyay, M. Simson, D. Seebach. Synthesis 1271 (1993). 
23. (a) J. Ipaktschi and A. Heydari. Chem. Ber. 126, 1905 (1993); (b) C. Anaya de Parrodi, E. Juaristi, L. Quintero, P. Amador. Tetrahedron: Asymmetry 7, 1915 (1996); (c) M. Sosa-Rivadeneyra, O. Munoz-Muniz, C. Anaya de Parrodi, L. Quintero, E. Juaristi. J. Org. Chem. 68, 2369 (2003).

24. (a) R. A. Jockusch, A. S. Lemoff, E. R. Williams. J. Am. Chem. Soc. 123, 12255 (2001); (b) T. E. Creighton, Proteins: Structures and Molecular Properties, $2^{\text {nd }}$ ed., W. H. Freeman, New York (1993); (c) P. Przybylski, G. Wojciechowski, B. Brzezinsky, H. Kozubek, S. Paszyk. J. Mol. Struct. 569, 147 (2001); (d) D. L. Boger and C. W. Boyce. J. Org. Chem. 65, 4088 (2000).

25. F. G. Riddell. Chirality 14, 121 (2002).

26. See, for example: P. Amrheim, P. L. Wash, A. Shivanyuk, J. Rebek, Jr. Org. Lett. 4, 319 (2002).

27. E. Juaristi, F. Díaz, G. Cuellar, H. A. Jiménez-Vázquez. J. Org. Chem. 62, 4029 (1997).

28. A computational study of the lithium affinity of $\mathrm{O}-\mathrm{C}-\mathrm{O}$ and $\mathrm{O}-\mathrm{C}-\mathrm{C}-\mathrm{O}$ systems has recently been presented: B. Ganguly and B. Fuchs. J. Phys. Org. Chem. 14, 488 (2001). 